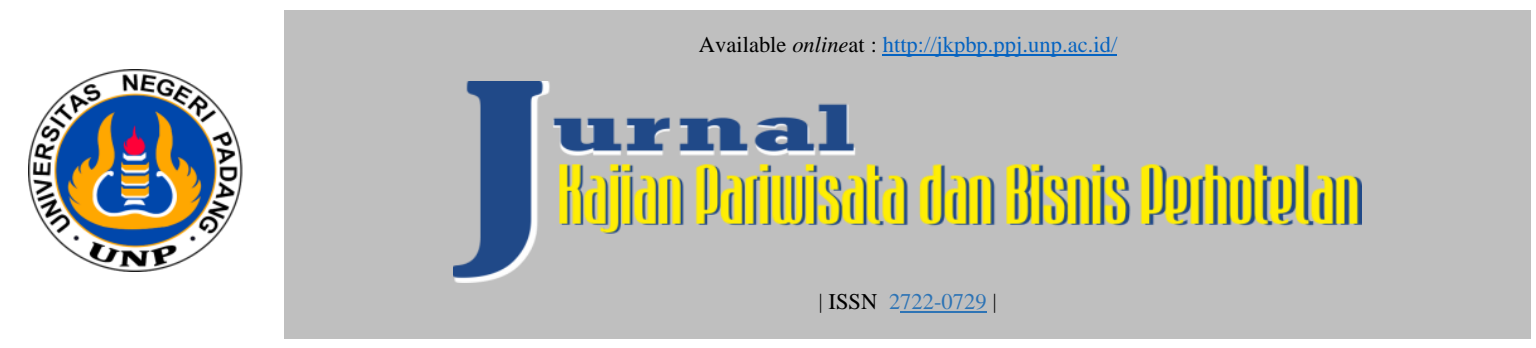

\title{
Pengaruh Pelatihan Terhadap Knowledge Karyawan di Artotel Sanur Bali
}

\author{
Gizel Gradinta Lineri ${ }^{1}$, Ira Meirina Chair ${ }^{2}$ \\ ${ }^{1}$ Universitas Negeri Padang \\ ${ }^{2}$ Universitas Negeri Padang \\ email : ggradinta@gmail.com , irameirinachair@gmail.com
}

\begin{abstract}
ABSTRAK
Penelitian didasarkan karena hasil tes knowledge karyawan di Artotel Sanur Bali, penulis menemukan beberapa masalah yaitu tidak ada posisi khusus yang menangani pelatihan untuk karyawan, karyawan yang memberikan jawaban pada tes kurang tepat, terdapat karyawan yang tidak mampu mengisi tes tertulis tentang product knowledge hotel dan job skills, masih terdapat karyawan yang tidak mengetahui lokasi dari fasilitas hotel. Urgensi dari penelitian ini adalah apabila tidak diatasi akan merusak citra hotel karena terdapat karyawan seharusnya memiliki pengetahuan terutama menyangkut product knowledge hotel dan job skill. Knowledge karyawan akan menunjang kelancaran operasional hotel dalam memberikan pelayanan kepada tamu.Tujuan dari penelitian ini yaitu mendeskripsikan pengaruh pelatihan terhadap knowledge karyawan di Artotel Sanur Bali.

Penelitian digolongkan kuntitatif metode assosiatif kausal.Populasi yaitu karyawan yang bekerja di Artotel Sanur Bali berjumlah 47 dengan teknik sampel jenuh.Selanjutnya dilakukan dengan menyebarkan kuesioner dengan metode skala likert serta dilakukan analisis terhadap data tersebut.

Berdasarkan penelitian, disimpulkan bahwa pengaruh pelatihan terhadap knowledge $22 \%$ serta $78 \%$ ditentukan lainnya.Koefisien regresi sebesar 0,490 signifikansi 0,001 $<0,05$. Disimpulkan bahwa terdapat pengaruh yang positif dan signifikan.Hipotesis penelitian yaitu $\mathrm{H}_{\mathrm{a}}$ diterima dan $\mathrm{H}_{0}$ ditolak.
\end{abstract}

\section{Kata kunci :Pelatihan, Knowledge, Karyawan}




\section{PENDAHULUAN}

Pariwisata semakin berkembang, dilihat dari semakin banyaknya kegiatan wisata yang dilakukan seperti belibur, berekreasi, ataupun berbulan madu ke tempat-tempat wisata.[1] Pariwisata adalah seluruh kegiatan berhubungan dengan wisatawan bersifat multidimensi serta multidisiplin demi mewujudkan kebutuhan setiap orang dengan cara interaksi antara konsumen.

Pulau Bali contohnhya, berkembang karena budaya tersendiri serta pantainya.Bali juga terkenal dengan makanan khasnya seperti ayam betutu dan icon-nya yaitu monumen Garuda Wisnu Kencana.Ibukota Bali yaitu Denpasar, juga terkenal dengan Monumen Bajra Sandhi, Museum Bali, dan Pantai Sanur.

Denpasar Selatan menjadi tujuan yang banyak diminati wisatawan jika berkunjung ke Denpasar.Terkenal dengan wilayah Sanur yang memiliki Pantai Sanur yang cocok untuk dijadikan tempat untuk bersantai dengan teman-teman atau keluarga.Potensi wisata Sanur, membuat industri pariwisatanya menjadi berkembang serta menghasilkan dampak positif bagi pengusaha terutama usaha hotel.[2] Hotel ialah usaha bisnis atau jasa berupa pelayanan serta menyediakan akomodasi, fasilitas penunjang yang dikelola secara komersial.

Artotel Sanur Bali berstandar hotel bintang empat yang berlokasi di Jalan Kusuma Sari nomor 1, Denpasar Selatan, Kota Denpasar, Bali.Artotel Sanur Bali memiliki departement yang berperan penting dalam mengelola sumber daya manusia yaitu Human Resource Department.Salah satu bentuk pengelolaan karyawan yaitu dengan memberikan pelatihan bagi karyawan.[3] Pemberian pelatihan penting dalam membentuk karatkter karyawan, karena setelah mengikuti pelatihan akan mengalami perubahan pada sifat dan mental. [4] Pelatihan (training) merupakan sebuah proses di mana karyawan memperoleh kapabilitas untuk membantu pencapaian tujuan individu dan organisasional. [5] Pemberian pelatihan dianggap sangat penting dalam membentuk karatkter karyawan, karena mayoritas pegawai yang telah mengikuti pelatihan akan mengalami perubahan pada sifat dan mentalnya dalam menerima arahan dalam bekerja.Namun berdasarkan tabel struktur organisasi Human Resource Department di Artotel Sanur Bali, tidak terdapat posisi khusus yang menangani pelatihan sumber daya manusia.Pelatihan yang diberikan kepada karyawan Artotel Sanur Bali dilakukan oleh Human Resource Manager bersama dengan penulis sebagai trainee. Tidak ada posisi khusus dalam menangani pelatihan untuk karyawan akanmenyebabkan adanya karyawan yang tidak memiliki knowledge (pengetahuan) mengenai produk dan keterampilan kerja. [6] Pengetahuan merupakan kesadaran dalam bidang kognitif. [7]Knowledgedibagi menjadi dua bagian yang saling berhubungan, Theoritical Knowledge dan Practical Knowledge.Adanya karyawan yang tidak memiliki knowledge (pengetahuan) mengenai produk hotel terlihat pada lembar hasil tes tertulis pada bagian hotel product knowledge pada November dan Desember 2019 yang dilakukan Human Resource Department. Karyawan memberikan jawaban yang kurang tepat dan mengosongkan kolom jawaban karena tidak memiliki knowledge terkait dengan product knowledge yang ada pada lembar tes.

Berdasarkan lembar hasil tes yang diisi oleh karyawan, terdapat karyawan yang memberikan jawaban kurang tepat dan mengosongkan kolom jawaban karena tidak memiliki knowledge terkait dengan job skill berdasarkan department pada masing-masing karyawan.Penulis juga menemukan langsung saat sedang bertugas mengawasi karyawan yang sedang bekerja, ada tamu yang bertanya kepada salah satu karyawan Front Office Department tentang lokasi Artotel Beach Club, yang merupakan salah satu properti Artotel yang lokasinya sudah diberikan pada saat Human Resource Manager memberikan pelatihan secara verbal sebelum adanya tes tertulis, dan karyawan tersebut tidak mampu menjawab pertanyaan tamu tersebut. Padahal karyawan sudah mendapatkan pelatihan dengan mengikuti beberapa kali tes tertulis mengenai product knowledge dan job skill knowledge. 


\section{METODOLOGI}

Penelitian ini digolongkan kepada kuntitatif dengan metode assosiatif kausal.[8] Penelitian assosiatifartinya bersifat menanyakan hubungan antara dua variabel atau lebih. Populasi yaitu karyawan yang bekerja di Artotel Sanur Bali dengan jumlah 47 memakai sampel jenuh.Selanjutnya data dikumpulkan dari kuesioner dengan metode skala likert serta data dianalisis.

\section{HASIL DAN PEMBAHASAN}

1. Deskripsi Data Pelatihan

Datavariabel pelatihandiperoleh dari 8 butir pertanyaan. Hasil penelitian dijabarkan sebagai berikut:

Tabel 1. Distribusi Frekuensi Data Pelatihan (X)

\begin{tabular}{|l|l|l|l|}
\hline Kategori & Rentang Skor & Frekuensi & Persentase \% \\
\hline Sangat Baik & $\geq 32$ & 0 & 0 \\
\hline Baik & $26,67-<32$ & 7 & 14,89 \\
\hline Cukup & $\mathbf{2 1 , 3 3 - < 2 6 , 6 7}$ & $\mathbf{2 6}$ & $\mathbf{5 5 , 3 2}$ \\
\hline Buruk & $16-<21,33$ & 14 & 29,79 \\
\hline Sangat Buruk & $<16$ & 0 & 0 \\
\hline Jumlah & 47 & 100 \\
\hline
\end{tabular}

Dari penelitian disimpulkan bahwa variabel pelatihan digolongkan pada kategori cuup baik dengan persentase sebesar 55,32\%.

\section{Deskripsi Data Knowledge}

Data variabel knowledgedidapat dari 9 butir pertanyaan. Hasilnya dapat dijabarkan sebagai berikut:

Tabel 2.Distribusi Frekuensi Data Knowledge (Y)

\begin{tabular}{|l|l|l|l|}
\hline Kategori & Rentang Skor & Frekuensi & Persentase \% \\
\hline Sangat Baik & $\geq 36$ & 0 & 0 \\
\hline Baik & $30-<36$ & 11 & 23,40 \\
\hline Cukup & $\mathbf{2 4}-<\mathbf{3 0}$ & $\mathbf{2 9}$ & $\mathbf{6 1 , 7 0}$ \\
\hline Buruk & $18-<24$ & 7 & 14,90 \\
\hline Sangat Buruk & $<18$ & 0 & 0 \\
\hline Jumlah & 47 & 100 \\
\hline
\end{tabular}

Hasil penelitian menunjukkanknowledge dikategorikan cukup baik dengan persentase sebesar $61,70 \%$.

\section{Uji Persyaratan Analisis}

a. Uji Normalitas

Terdapat nilai Assymp Sig variabel pelatihan ialah 0,189 kemudian 0,661 untuk variabel knowledge. 


\section{b. Uji Homogenitas}

Terdapat nilai sig $0,104>0,05$. Maka nilai signifikansi lebih besar dari pada taraf signifikansi.

c. Uji Lineritas

Terdapat nilai sig 0,794 >0,05, maka terdapat hubungan linear antara pelatihan dan knowledge.

\section{Pengujian Hipotesis}

Dari pengujian hipotesis, diperoleh hasil pengaruh pelatihan terhadap knowledge sebesar 22\% sedangkan $78 \%$ ditentukan lainnya. Hipotesisnya ialah $\mathrm{H}_{\mathrm{a}}$ diterima dan $\mathrm{H}_{0}$ ditolak.

\section{Pembahasan}

\section{a. Pelatihan $(\mathbf{X})$}

[9] Pelatihan yaitu kegiatan yang dilakukan untuk pengembangan profesional.Berdasarkan penelitian tentang variabel pelatihan, dijelaskan dari 47 orang responden, disimpulkan bahwa variabel pelatihan digolongkan kategori cukup baik dengan persentase55,32\%. Selanjutnya deskripsi indikator: 1) Reactions (reaksi), dikategorikan buruk 40,42\%, 2) Learning (belajar), dikategorikan cukup baik 53,19\%, 3) Result kategori cukup baik 44,68\%.

Berdasarkan penelitian yang telah dilakukan dapat disimpulkan bahwa variabel lingkungan pelatihan di Artotel Sanur Bali dikategorikan cukup baik, selanjutnya pihak hotel harus meningkatkan hasil pelatihan dari setiap karyawan menjadi sangat baik dengan cara mengadakan pelatihan untuk setiap karyawan secara berkala, memberikan materi pelatihan sesuai dengan section dari setiap karyawan, serta mendatangkan pemateri yang kompeten, hal tersebut bertujuan agar dapat menambah ilmu pengetahuan dari setiap karyawan dan membuat karyawan akan lebih produktif dalam menyelesaikan pekerjaannya.

\section{b. Knowledge (Y)}

[10] Pengetahuan berarti seseorang yang mengetahui informasi dari bidangnya sendiri.

Berdasarkan hasil penelitian tentang variabel knowledge, dapat dijelaskan dari 47 responden, dapat disimpulkan bahwa knowledge karyawan di Artotel Sanur Bali digolongkan pada kategori cukup baik dengan persentase sebesar 61,70\%. 1) Pendidikan, digolongkan buruk, 2) Pengalaman kategori baik, 3) Minat, dikategorikan cukup baik. Berdasarkan penelitian yang telah dilakukan, dapat disimpulkan bahwa knowledge karyawan di Artotel Sanur Bali dikategorikan cukup baik. Selanjutnya pihak hotel harus meningkatkan knowledge dari setiap karyawan menjadi sangat baik menetapkan standar pendidikan yang harus dimiliki setiap karyawan, menjalankan SOP yang telah dibuat, melakukan seleksi kepada karyawan yang baru masuk dari pengalaman serta penghargaan yang dimiliki, serta mengembangkat minat yang dimiliki oleh setiap karyawan. Hal tersebut bertujuan untuk melihat potensi knowledge dari setiap karyawan.

\section{c. Pengaruh Pelatihan Terhadap Knowledge Karyawan di Artotel Sanur Bali}

Berdasarkan pengujian hipotesis, didapat pengaruh pelatihan terhadap knowledge 22\% sedangkan $78 \%$ ditentukan lainnya, signifikasi $0,001<0,05$. Maka disimpulkan bahwa terdapat pengaruh yang positif antara pelatihan (X) terhadap knowledge di Artotel Sanur Bali.Hipotesis $\mathrm{H}_{\mathrm{a}}$ diterima. 


\section{KESIMPULAN}

1) Secara keseluruhan variabel Pelatihan (X), digolongkan cukup baik. Sedangkan berdasarkan 3 indikator terdapat 2 indikator kategori cukup baik yaitu indikator learning (belajar) dan indikator result (hasil) serta 1 indikator kategori buruk yaitu indikator reactions (reaksi).

2) Secara keseluruhan variabel Knowledge Karyawan (Y) digolongkan cukup Baik. Sedangkan berdasarkan 3 indikator terdapat 1 indikator kategori baik yaitu indikator pengalaman, 1 indikator kategori cukup baik yaitu indikator minat serta 1 indikator kategori buruk yaitu indikator pendidikan.

3) Pengaruh pelatihan terhadap knowledge 22\%, 78\% ditentukan lain. Signifikansi 0,001 < 0,05, disimpulkan bahwa terdapat pengaruh positif antara pelatihan terhadap knowledge di Artotel Sanur Bali. Hipotesis $\mathrm{H}_{\mathrm{a}}$ diterima. 


\section{DAFTAR PUSTAKA}

[1] N. 10 T. 2009 Undang-Undang Republik Indonesia, Undang-Undang no. 10 Tahun 2009 tentang Kepariwisataan.

[2] Nurita, Wayan dan Meidariani, Ni Wayan. 2020. Bahasa Jepang Perhotelan: Effective Japanese for Hotel Staff. Bali: Nilacakra. Tersedia di https://books.google.co.id/books?id=lpHcDwAAQBAJ\&pg=PA7\&dq=pengertian+hotel\&hl= id\&sa=X\&ved=2ahUKEwjK6f-

t frAhVpIbcAHcfBe8QuwUwAXoECAYQCA\#v=onepage\&q

=pengertian\%20hotel\&f=false. Diakses 20 September 2020.

[3] Prastyo, Tri Hantoro Wasis. 2018. Pengaruh Pelatihan Terhadap Kinerja Karyawan dengan Motivasi Sebagai Variabel Mediasi Karyawan PT. Hanil Indonesia Boyolali. Sukoharjo: IAIN Surakarta. Tersedia di http://eprints.iain-surakarta.ac.id/3987/1/SKRIPSI.pdf.Diakses 4 Oktober 2020.

[4] Chaerudin, Ali. 2019. Manajemen Pendidikan dan Pelatihan SDM. Sukabumi: CV Jejak, anggota IKAPI. Tersedia di https://books.google.co.id/books?id= 3C6LDwAAQBAJ\&printsec $=$ frontcover $\& \mathrm{dq}=$ pengertian+individual+knowledge+karyawan $\&$

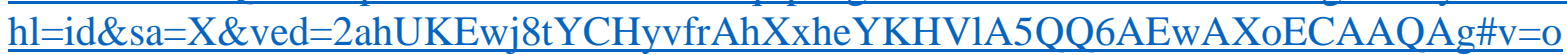
nepage\&q\&f=false. Diakses 20 September 2020.

[5] Prastyo, Tri Hantoro Wasis. 2018. Pengaruh Pelatihan Terhadap Kinerja Karyawan dengan Motivasi Sebagai Variabel Mediasi Karyawan PT. Hanil Indonesia Boyolali. Sukoharjo: IAIN Surakarta. Tersedia di http://eprints.iain-surakarta.ac.id/3987/1/SKRIPSI.pdf.Diakses 4 Oktober 2020.

[6] Tamara, Pinky Dwi Annisa. 2019. Analisis Pengaruh Pengetahuan, Sikap, danPengalaman Kerja Karyawan Terhadap Kinerja Karyawan LembagaKeuangan Mikro Syariah di Tulungagung. Tulungagung: IAINTulungagung. Tersedia di http://repo.iaintulungagung.ac.id/12257/5 /BAB\%20II.pdf.Diakses 4 Oktober 2020.[6] Pratiwi, Nur Endah. 2018. Pengaruh Dimensi Kompetensi Terhadap Kinerja

[7] Novalika. 2016. Pengetahuan, Kemampuan, dan Loyalitas Terhadap Kinerja Karyawan Dinas Kebudayaan dan Pariwisata Provinsi Sumatera Selatan. Palembang: Universitas Muhammadiyah Palembang. Tersedia di http://repository.umpalembang.ac.id/id/eprint/944/1/SKRIPSI757-1705192 720.pdf.Diakses 4 Oktober 2020.

[8] Sugiyono. 2015. Metode Penelitian Kuantitatif, Kualitatif, dan R\&D. Bandung: ALVABETA.

[9] Sinaga, Onita Sari dkk. 2020. Manajemen Kinerja dalam Organisasi. Medan: Yayasan Kita Menulis. Tersedia di https://books.google.co.id/books?id=0kX8DwAAQBAJ\&pg=PA87\&dq =pelatihan+SDM\&hl=id\&sa=X\&ved=2ahUKEwjizOilz frAhXz73MBHTJQBtIQ6AEwA3o ECAMQAg\#v=onepage \&q=pelatihan\%20SDM\&f=false. Diakses 20 September 2020.

[10]Pegawai pada Tenaga Kerja Kota Cimahi. Bandung: Universitas Pasundan. Tersedia dihttp://repository.unpas.ac.id/33043/3/BAB2\%5B1\%5D.pdf.Diakses 4 Oktober 2020. 